\title{
NUMERIKUS MECHANIKAI MÓDSZEREK ALKALMAZÁSA SZERSZÁMGÉPEK FEJLESZTÉSE SORÁN
}

\author{
Szilágyi Attila \\ egyetemi docens, Miskolci Egyetem, Szerszámgépészeti és Mechatronikai Intézet \\ Szerszámgépek Intézeti Tanszéke \\ 3515 Miskolc, Miskolc-Egyetemváros, e-mail: szilagyi.attila@uni-miskolc.hu
}

\author{
Kiss Dániel \\ egyetemi tanársegéd, Miskolci Egyetem, Szerszámgépészeti és Mechatronikai Intézet \\ Szerszámgépek Intézeti Tanszéke \\ 3515 Miskolc,Miskolc-Egyetemváros, e-mail:kiss.daniel@uni-miskolc.hu
}

\begin{abstract}
Absztrakt
Cikkünkben szerszámgépek fejlesztése során felmerülő mechanikai és hötani problémák vizsgálatára alkalmazott numerikus módszerek egyikének rövid, alkalmazástechnikai éttekintését végezzük el. Példaként egyes, általunk megoldott problémák eredményeit is bemutatjuk. Elsöként röviden összefoglaljuk azon jelenségköröket, ahol a numerikus eszközök, módszerek alkalmazása megkerülhetetlen. Általános analitikus probléma rövid bemutatásán keresztül igazoljuk a numerikus ezközök létjogosultságát. Cikkünkben a számos numerikus módszer közül a végeselemes módszer (FEM) szerszámgépészeti irányú bemutatására térünk ki. Rövid példák segitségével mutatjuk be a végeselemes módszer alkalmazhatóságát, az általuk elérhetö eredményeket, így végsö soron igazoljuk a módszer szerszámgépek fejlesztése során megtapasztalt hatékonyságát.
\end{abstract}

Kulcsszavak: Szerszámgép, numerikus, mechanikai, melegedés, végeselem

\begin{abstract}
This paper gives a brief summary on the mechanical and thermal applicability of the finite element method (FEM) from the field of designing procedure of machine tools. The solutions of certain problems, as examples, are also demonstrated. First the summary of such phenomena is performed, where the application of numerical methods is inevitable. Through the brief summary of the general problem of elasticity, the justification of the numerical methods is demonstrated. Finally, examples are set to demonstrate the applicability of the numerical methods and the achieved results, which demonstrate the efficiency of the FEM applied for the development of machine tools. Among several numerical methods the FEM is focused on in this paper.
\end{abstract}

Keywords: Machine-tools, numerical, mechanical, thermal, FEM

\section{Bevezetés}

Egy megmunkálóberendezés vagy szerszámgép üzemeltetése során számos, a megmunkálópontosságot jelentős vagy kevésbé jelentős mértékben befolyásoló jelenségkör előfordulásával kell számolni, például a kinematika, a dinamika, a szilárdságtan, illetve a hőtan területeiről. E tényezők befolyását már a megmunkálóberendezés tervezési fázisában, vagyis anélkül, hogy a berendezés ténylegesen (fizikailag) rendelkezésre áll, célszerü megítélni. Berendezés hiányában ennek megítélését kizárólag csak analitikus, illetve numerikus matematikai-mechanikai 
eszközökkel tudjuk elvégezni. Ehhez járulhat még egy, a tervezendő berendezéshez hasonló berendezésen végzett mérési sorozat.

A fent említett jelenségkörök matematikai leírása sokszor bonyolult, ráadásul nemlineáris közönséges vagy parciális differenciálegyenletre/egyenletrendszerre vezet, melyek egzakt, illetve még közelítő analitikus megoldása is - a geometriából adódó bonyolult peremfeltételek miatt - közismert nehézségekbe ütközik. E nehézségek kiküszöbölésére számos numerikus eljárás kifejlesztése vált szükségessé. Legelterjedtebben és talán legjobb közelítést biztosító jellege miatt a végeselemes számítási módszert alkalmazzák.

Cikkünkben néhány egyszerủ példán keresztül mutatjuk be a végeselemes módszer szerszámgépek fejlesztése során megtapasztalt lehetőségeit, sokrétüségét. A továbbiakban elöször a modellezés szükségességét, illetve a modellezés által elérhető jelenségköröket foglaljuk össze.

\section{Szerszámgépek üzemeltetése során fellépő jelenségek köre}

Egy megmunkálóberendezés vagy szerszámgép működése során fellépő - sok esetben káros, vagyis a megmunkálási pontosságot negatív irányba befolyásoló, sokszor egymással is összefüggő - jelenségek alapvetően három fizikai területről származnak: kinematika, mechanika, hőtan.

Kinematikai ,jelenségek” közé soroljuk a geometriai pontatlanságból eredő, ideális geometriai entitásoktól való eltérésből adódó problémákat, pl. egyenesség-eltérés, merölegességi probléma, gömbalakhűség, futási pontatlanság stb. Ezek kimutatása csak létező berendezésen lehetséges, előzetes becslésük a tervezési folyamat során elvégzésre kerülő türéstechnikai számítások alapján történik. Megjegyezzük, hogy a korszerü 3D-s integrált mérnöki tervezőrendszerek általában lehetővé teszik ilyen jellegü számítások elvégzését, melyeket azonban nem sorolunk a „klasszikus” szimulációk közé, így a továbbiakban kinematikai jelenségekkel nem foglalkozunk. Felmerülhet még a kinematikai szimuláció kapcsán adódó tehetetlenségi erők kérdése, ezeket azonban inkább dinamikai jelenségek kapcsán vizsgáljuk szilárdságtani, valamint törésmechanikai állapot, illetve viselkedés leírására.

Mechanikai jellegü jelenségek között megemlíthetjük a berendezés működése során fellépő terhelési állapothoz köthetőket (pl. érintkezési feszültségek, feszültséggyüjtőhelyek stb), a terhelési állapot eredményeként adódó alakváltozással kapcsolatosakat (pl. gördülőelemek, vezetékek, főorsók deformációja), elmozdulásokat (vágóél és megmunkált felület deformációs relatív elmozdulásai), különös tekintettel a képlékenyalakváltozásokra. Idesorolhatók továbbá áramlástani (hütő-kenő fluidumok), tribológiai (csúszóvezetékek stick-slip jelenségei, aerosztatikus vezetékek), kenéselméleti jelenségek (hidrosztatikus és hidrodinamikus vezetékek). Ugyancsak mechanikai problémák tág részhalmazát foglalják el a dinamikai jelenségek (pl. a korábban emlegetett tehetetlenségi erők), az ezekből fakadó rezgéstani jelenségek igén széles köre [6][7] (szabad-, gerjesztett, öngerjesztett, parametrikusan gerjesztett rezgési jelenségek), illetve ezek eredményeként - szélsőséges esetekben kialakuló - kifáradási és egyéb törésmechanikai jelenségek. Rezgéstani jelenségek közül kiemelhetjük a hajtószíjak erősen nemlineáris transzverzális [3], a fö- és mellékhajtások közel lineárisnak tekinthető torziós rezgési jelenségeit [2], valamint a megmunkálások által keltett, általában erősen sztochasztikus jellegü rezgéseket. A mechanikai jelenségek közül külön kiemelnénk az érintkezési (kontakt) jelenségek széles körét, hiszen egy megmunkálóberendezésben kialakuló erőfolyamot, amely egyébként az imént felsorolt jelenségek szinte mindegyikét előidézi vagy legalábbis befolyásolja, mindig az egymással közvetlenül kapcsolódó gépelemek érintkezési feszültségmezői építik fel, így ezek helyes - és viszonylag egyszerü módon történő - számbavétele (pl. a Saint-Venant-elvet kihasználva) kiemelt jelentőségü egy jó közelítést biztosító numerikus szimuláció definiálásához. 
Hőtani (melegedési) jellegủ jelenségek közül megemlítjük a berendezés egységei által generált hőforrások hatásait, a hővezetés és hőterjedés jelenségeit, ezek eredményeként kialakuló hőeloszlás és hődeformáció jelenségét, illetve a különféle hőtranszport folyamatokat, melyek például a megmunkálási folyamatok hütő-kenő hatásosságának vizsgálatakor merülnek fel. Megjegyezzük, hogy a hőtani jelenségek vizsgálata - attól függően, hogy tranziens vagy stacionárius - eltérő bonyolultságú lehet, számítási igénye jelentősen meghaladhatja a mechanikai jellegüekét [4].

Megemlíthetünk még egyéb, a fenti jelenségkörökbe nem besorolható, más területekről származó jelenségeket is, amelyek azonban a berendezés müködése során előidézői lehetnek mechanikai vagy hőtani jelenségnek. Megemlíthetjük például a lineáris motoros hajtásokkal összefüggő villamoságtanimágneses jelenségeket, ezek közül is a síklineáris motor egyik káros, ún. parazita erővel kapcsolatos jelenségét, amely első sorban csúszóvezetékes előtoló egységek esetén - a megnövekedett súrlódási erő miatt - jelentős teljesítményigényt támaszt. Megemlíthetjük továbbá a hajtásszabályozások nemlineáris villamosjelenségeit, amelyek egy CNC előtolóegység pozicionálási pontosságát befolyásolhatja kedvezőtlen irányba. Különleges optikai eredetü jelenség említhető ultraprecíz lézeres „megmunkálóberendezés” esetén, amikor a viszonylag hosszú koherenciahosszal rendelkező lézert hologram írására használjuk. Ekkor, mivel a lézernyalábok „szabadban” is haladnak, lényeges a lézernyalábot tartalmazó légtömeg törésmutatójának állandósága, ezért az alkalmazott lineáris hajtás hütését gondosan kell megtervezni.

Ismeretes, hogy a fenti jelenségek sokszor egymással együtt, rendszerint csatoltan, vagyis egymásra hatást kifejtve, szélsőséges esetben egymás hatását felerősítve fordulnak elő. Példaként említhetjük egy nagy tömeget hordozó, statikai merevség szempontjából elégtelen forgó tengelyen bekövetkező kiegyensúlyozatlanságból eredő alakváltozást és elmozdulást, amely adott esetben a forgó tengely nagy amplitúdójú parametrikus lengéseit idézheti elő. Másik példaként a hődeformációs folyamat említhető, amely hőtani (melegedés) és szilárdságtani (alakváltozás) jelenségek együttes eredménye, jelentős mértékben - általában kedvezőtlen irányba - befolyásolva a megmunkálási pontosságot. Érdekességként jegyezzük meg, hogy az imént számba vett jelenségek - talán az optikai kivételével - egyszerre fordulhatnak elő modern megmunkálóberendezések motororsó rendszerében, így ennek az egységnek az elméleti vizsgálata - főleg a tervezési fázisban - komoly kihívás a szerszámgépfejlesztő csoportnak.

Fenti jelenségek kísérleti jellegü vizsgálata az [1] munkában követhető nyomon.

\section{A numerikus eszközök szükségszerüsége}

Az imént bemutatott jelenségek analitikus vizsgálata még lineárisnak feltételezett törvényszerüségek mellett is - a bonyolult kinematikai és dinamikai peremfeltételekből fakadóan - közismert nehézségekbe ütközik. Példaként tekintsük az alábbi - jól ismert - ábrát, amely a rugalmasságtan alapfeladatát mutatja (1. ábra).

Ilyen feladat megoldása lényegében a terhelés alatt álló rugalmas test terhelési és alakváltozási állapotának, illetve elmozdulás-mezőjének elő́llítására irányul. Ezt analitikusan az alábbiak szerint fogalmazhatjuk meg [5].

A keresett elmozdulás-mezőt jelölje $\vec{u}(\vec{r})=u \vec{e}_{x}+v \vec{e}_{y}+w \vec{e}_{z}$, az alakváltozási és feszültségi tenzormezőket pedig $\underline{\underline{A}}=\underline{\underline{A}}(\vec{r})$, illetve $\underline{\underline{T}}=\underline{\underline{T}}(\vec{r})$, melyek szintén a helykoordináták függvényei. A szimmetria miatt összesen $3+6+6=15$ mezőt kell meghatározni, melyekhez az alábbi egyenletek állnak rendelkezésre. 


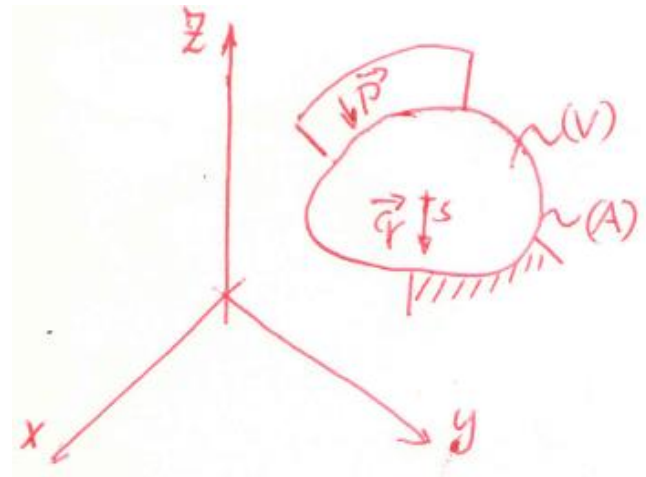

1. ábra. A rugalmasságtan alapfeladata.

Felírható a

$$
\underline{\underline{A}}=\frac{1}{2}(u \circ \nabla+\nabla \circ u)
$$

geometriai egyenlet, a

$$
\underline{T} \cdot \nabla+\vec{q}=\overrightarrow{0}
$$

egyensúlyi egyenlet, valamint a

$$
\underline{\underline{T}}=\underline{\underline{D}} \cdot \stackrel{\underline{A}}{=}
$$

anyagegyenlet, amely legegyszerübb esetben a Hooke-törvényt rejti magában. Mindezek mellett rendelkezésre állnak még a kinematikai $\vec{u}=\vec{u}_{0}\left(\vec{r} \in A_{u}\right)$ és dinamikai $\underline{\underline{T}} \cdot \vec{n}=\vec{p}\left(\vec{r} \in A_{p}\right)$ peremfeltételek, ahol egyébként $A_{u} \cup A_{p}=A$.

Bonyolult geometriák esetén (pl. hegesztett vagy öntött gépágyak, bonyolult lépcsős főorsótengelyek, gördülőelemes mellékhajtások stb) a fenti, parciális differenciálegyenlet-rendszerre alapozott elméleti vizsgálat egzakt módon nem végezhető el. Ennek ellenére a gépészmérnöki gyakorlat mégis igényli ilyen és ennél bonyolultabb jelenségekkel kapcsolatos problémák megoldását - sokszor még a gépágyénál is jóval összetettebb geometriai peremfeltételek mellett - így a felmerülö nehézségek kiküszöböléséhez a mérnöki gyakorlat inkább az úgynevezett numerikus mechanikai eszközök felé fordul, és igyekszik tetszőleges pontosságú közelítő megoldást előállítani például a fenti rugalmasságtani probléma megválaszolására. Számos ilyen - általában integrált mérnöki tervezőrendszer szerves részét képező, numerikus elvü - szoftver áll a gépészmérnök rendelkezésére. A továbbiakban a gépészmérnöki gyakorlatban legsokoldalúbban alkalmazható végeselemes módszer alkalmazástechnikai jellemzöit tekintjük át, különös tekintettel annak szerszámgépészeti vonatkozásait.

\section{A végelemes módszer szerszámgépészeti vonatkozásai}

A végeselemes módszer - egyéb más numerikus eljárásokkal (pl. differencia módszer, kollokációs eljárás stb) ellentétben - nem közvetlenül az eredeti parciális differenciálegyenlet-rendszer közelítő megoldását álltja elö, hanem kikerülve azt, variációs elvek alapján szolgáltat közelítő megoldást. Ennek részletei megtalálhatók pl [5]-ben. A módszer alkalmazásának kiindulási pontja minden esetben 
egy alkalmasan megalkotott modell. Ez a modell manapság - a modern integrált mérnöki tervezörendszereknek köszönhetően - rendszerint egy ún. digitális prototípus (2. ábra). Az ábra egy szürkeöntvény kupola-szerü gépállványt jelenít meg. Szóban forgó gépegység az „Ultrapontosságú és Freedome típusú szerszámgépek kifejlesztése” c. GINOP-2.2.1-15-2017-00093 projekt keretében kifejlesztésre kerülő nagypontosságú maróberendezés gépállványának központi eleme. Mivel a fejlesztés alatt álló maróberendezés újszerüségéhez jelentős mértékben hozzájárul, így kialakítása során számos mechanikai és hőtani tulajdonságait kellett feltárni, majd a geometriáját az előzetesen rögzített követelményrendszernek megfelelő módon kialakítani. Ennek során szilárdságtani és dinamikai jellemzők sokaságát kellet feltárni, és ezeket - részben egymással összefüggően figyelembe véve törekedtünk az optimális geometria kialakítására.

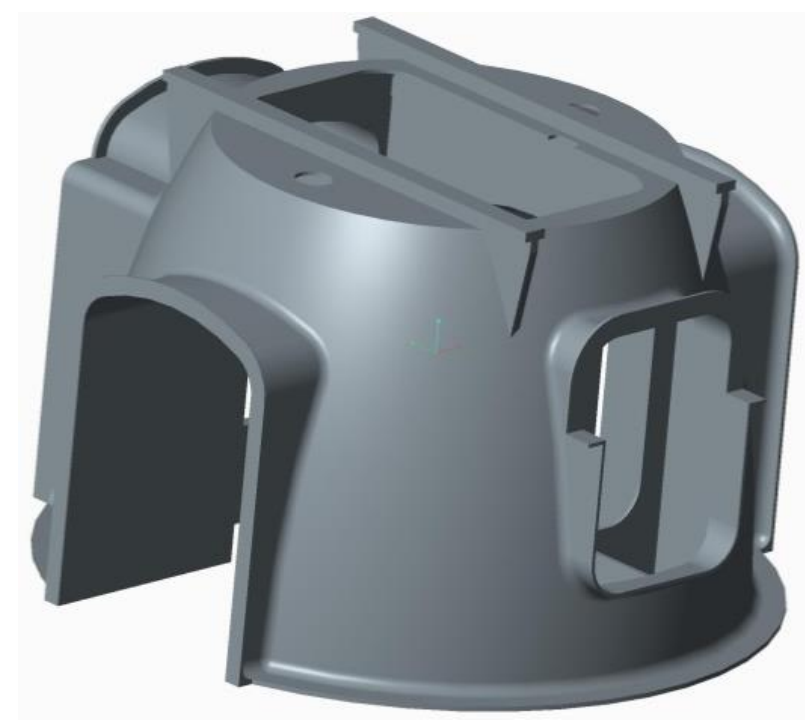

2. ábra. A gépállvány FEM analiziséhez használt digitális prototípus.

Ultraprecíz fúró-maró megmunkáló berendezésről lévén szó, a teljes gépállvány központi egységének egyik sarokponti jellemzője a statikai merevség, amely időben állandó terhelésre adott elmozdulás-válasz. Maró megmunkálás során ugyanis a fellépő, időben változó előtolóerő-komponens zérustól különböző középértékkel rendelkezik, melyre szuperponálódik az idöben - jó közelítéssel periodikusan változó összetevő, így statikai merevség szempontjából elégtelen gépállvány esetén a megmunkálási pontosság romlása jelentős. Hasonló jelentőséggel bír a konstrukció dinamikai merevsége, mely az időben - általában periodikusan - változó terhelésre adott válaszfüggvény formájában fejezhető ki, és lényegében a gerjesztésre adott, kitüntetett irány mentén értelmezett elmozdulás-amplitúdó mértékével jellemezhető. Ez szélsőséges esetben rezonáns állapotot is jelenthet. A dinamikai merevség megállapítására vonatkozó szimuláció alapját a 3D-s környezetben végzett modálanalízis jelenti, melynek során - esetünkben lineáris anyagtörvényt feltételezve - elöállítjuk a vizsgált modell tetszőleges számú sajátfrekvenciáját és a hozzájuk tartozó lengésképeket. Célunk ebben az esetben olyan geometria kialakítása volt, amely minél magasabb legkisebb sajátfrekvenciával rendelkezik, felfelé kitolva ezt a frekvenciaértéket a lehetséges megmunkálási frekvenciatartományból, minimalizálva így annak valószínűségét, hogy nagyoló megmunkálás során rezonáns állapot fordulhasson elö. Az alábbi ábra az egyik változat legkisebb sajátfrekvenciához tartozó lengésképét mutatja (3. ábra). 


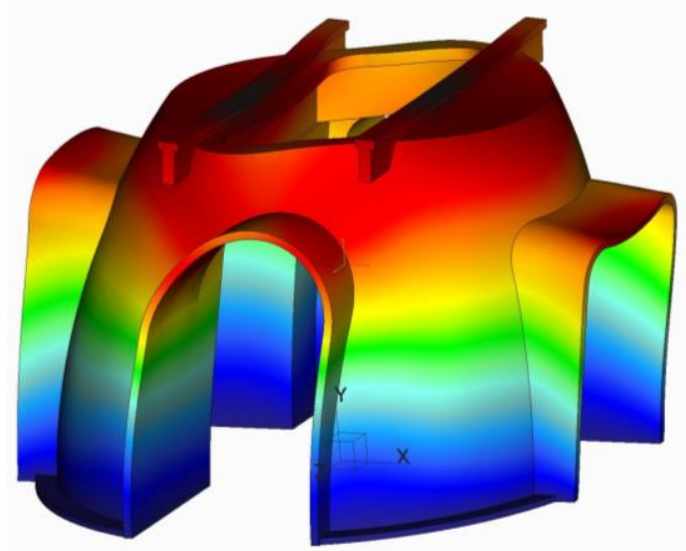

3. ábra. A legkisebb sajátfrekvenciához tartozó lengéskép.

A fenti 3D-s modell számos további analízisen esett át. Dinamikai jellegú volt ezek közül a már korábban említett modálanalízis, az ezt követő dinamikai merevségi mutatókat előállító analízis, a harmonikus, illetve impulzus gerjesztések hatására bekövetkező rezgésállapot vizsgálata, különféle csillapítási együtthatók figyelembevétele, végül pedig az optimális geometria kialakítása. Szilárdságtani (statikus) jellegủ vizsgálatok között elvégeztük a statikus merevségi mutatószámok előállítását, érintkezési feszültségek kiszámítását, előfeszítések figyelembevételét, ellenőriztük vezetékek felületi igénybevételét, és a fenti jellemzőkre - geometriai változók függvényében érzékenységi vizsgálatokat is végeztünk. Könnyen belátható, hogy ezek a vizsgálatok - a bemutatott bonyolult geometria mellett - nem nélkülözhetik a numerikus mechanikai eszközeit. Az alábbi diagram rezonáns állapotot mutat be, a legkisebb sajátfrekvencián történő harmonikus gerjesztésre adott válaszfüggvényt mutatja a konstrukció egy kitüntetett pontjában (4. ábra). E diagramok segítségével a különféle csillapítások hatásait vizsgáltuk.

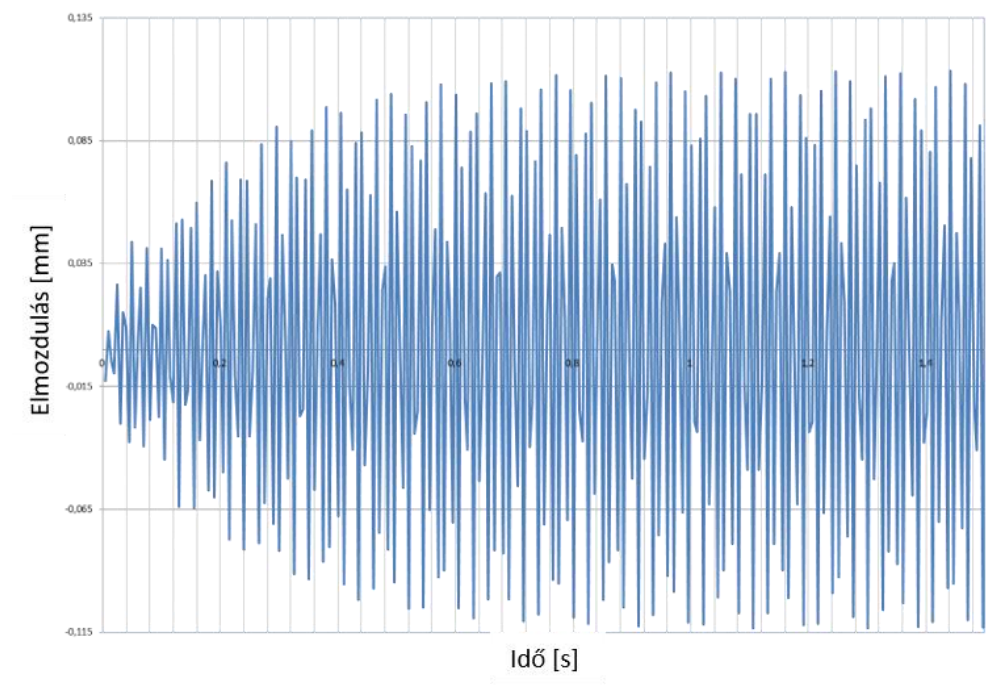

4. ábra. Rezonáns állapot szimulációs környezetben. 
Dinamikai jellegü mellett számos szilárdságtani (statikus) jellegü vizsgálatot is végeztünk. A fentiekben említettük, hogy a 2. ábra által megjelenített egység a teljes gépállvány központi, az egész berendezés szempontjából az egyik újdonságot hordozó eleme. E mellett a teljes gépállvány statikus merevséggel összefüggő jellemzőit is vizsgáltuk, melynek a berendezés telepítése céljából volt jelentősége, lévén a teljes berendezés előzetesen becsült tömege 60 tonna! Az alábbi ábra a teljes gépállványt mutatja (5. ábra).

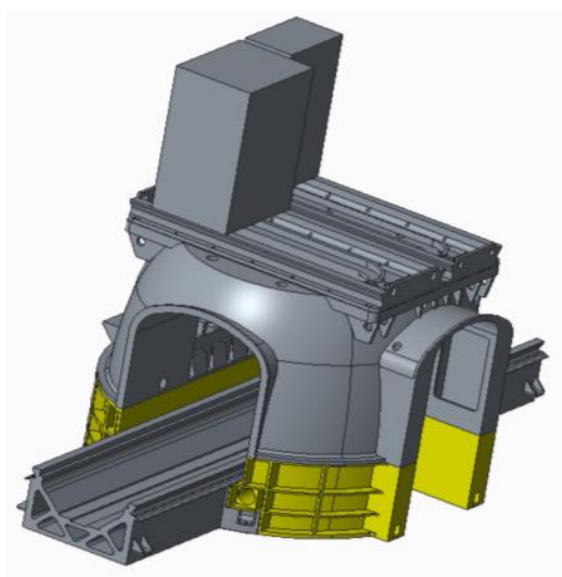

5. ábra. A teljes gépállvány összeállitási modellje.

Az ábrán megfigyelhetö - a központi elemen elhelyezkedő - hasáb alakú egységek a még tervezési fázisban lévő nagyoló és simító megmunkálásokat végző szánegységeket szimbolizálják. Vizsgálataink során képet szerettünk volna kapni arról, hogy hogyan viselkedik a teljes gépállvány telepítés során, szerelés közben, amikor a szilárd talajra való felfekvés csak a támasztó csapokon keresztül történik, és hiányzik az állvány alsó felülete és a talaj közötti kitöltő anyag. E vizsgálat egyik részét képezte a teljes gépállvány saját tömegéből adódó térfogati terhelés hatására bekövetkező deformációs állapot feltárása. Az anyagjellemzőket, a kinematikai és dinamikai peremfeltételeket, valamint a végeselemes hálót tartalmazó szilárdságtani modell az alábbi ábrán látható (6. ábra).

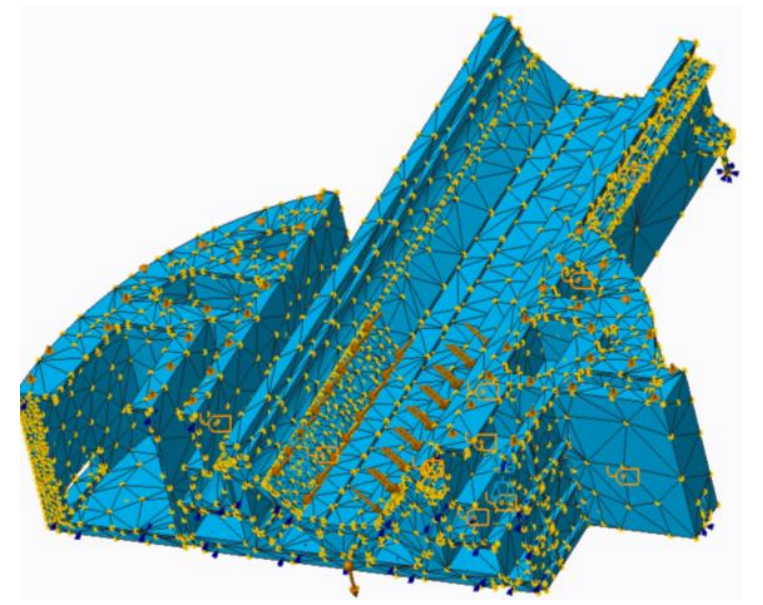

6. ábra. A szimmetriát kihasználó szilárdságtani modell. 
Az ábrán megfigyelhető a geometria, valamint a peremfeltételek szimmetriáját kihasználó egyszerüsítés: a szimmetrikus viselkedés előírása mellett elég csak a geometria adott résztartományát vizsgálatba vonni, így elöírt számítási idő mellett pontosabb analízis, illetve elöírt pontosság mellett rövidebb számítási idő érhető el. A fenti módon definiált, előfeszített csavarkötéseket is tartalmazó érintkezési feladat megoldására többek között az alábbi elmozdulás mező adódott (7. ábra).

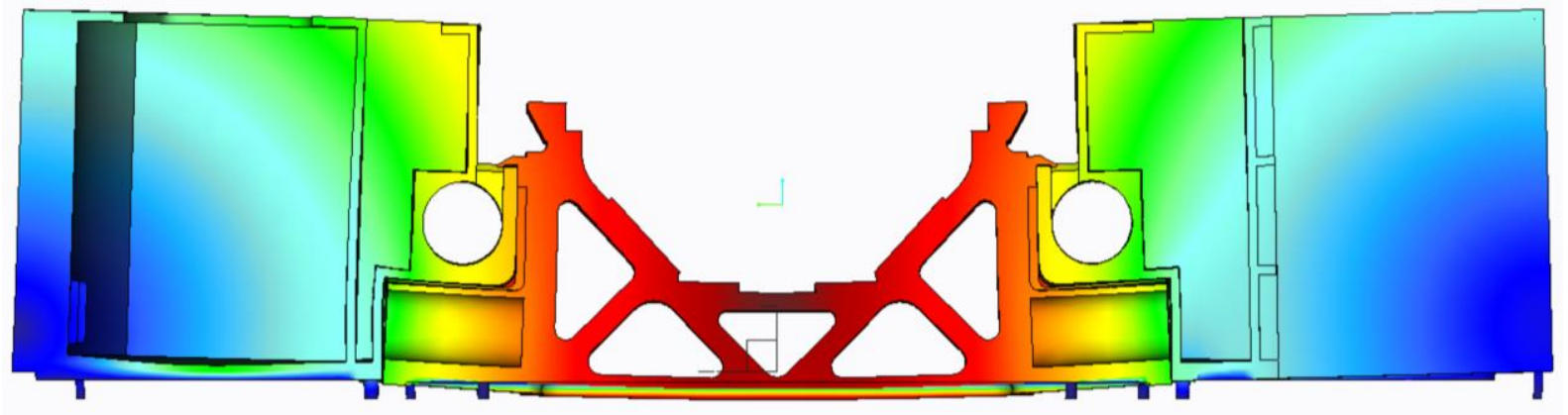

7. ábra. A deformált állapotú elmozdulásmezö az egyik kitüntetett keresztmetszetben.

Az imént vázolt részanalízis megerősítette a konstruktör sejtését, amely szerint a gépállvány $\mathrm{X}$ ágya további, talajra felfekvő támaszokat kíván a nagy mértékủ deformációknál megjelenő mechanikai feszültségértékek kompenzálására, így a berendezés telepítése során fellépő törésveszély valószínűségének minimalizálására.

Hasonló szilárdságtani probléma merült fel a berendezés orsótőke rendszerü nagyolóegységének statikus merevségével kapcsolatban. Az orsótőke ugyanis $800 \mathrm{~mm}$-es lökethosszú, így a nagyoló megmunkáláskor fellépő terhelés az orsótőkét - annak kinyúlása függvényében - eltérő mértékben hajlítja. Egy adott kinyúlás mellett a deformált állapotban megjelenő elmozdulásmező az alábbi ábrán látható (8. ábra). A piros színnel megjelenő elem az orsótőke, amely a megmunkáló szerszámot hordozza.

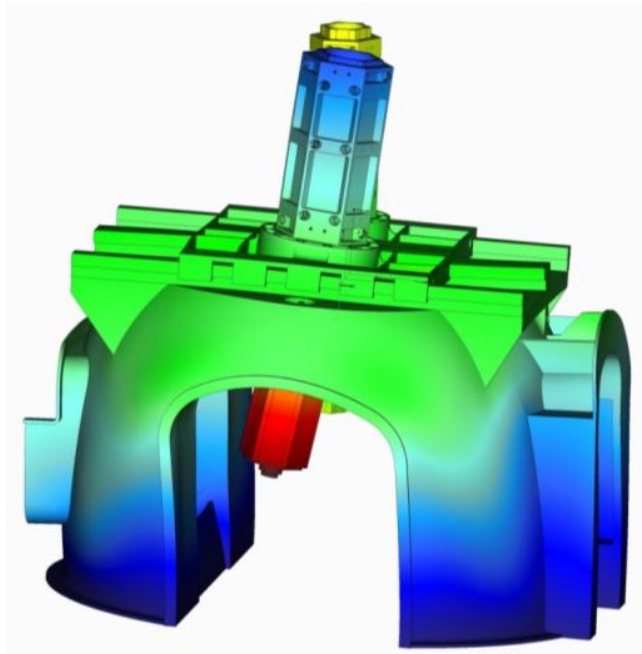

8. ábra. Az orsótöke hajlitó igénybevétele nagyoláskor. 
Az egyes orsótőke-kinyúlásokhoz tartozó vizsgálatainkat egy érzékenységi vizsgálat foglalja össze melynek során diagram formájában tárjuk fel az orsótőke kitüntetett (vég)pontjának elmozdulását annak kinyúlása függvényében a kitüntetett pontban fellépő adott terhelés hatására (9. ábra).

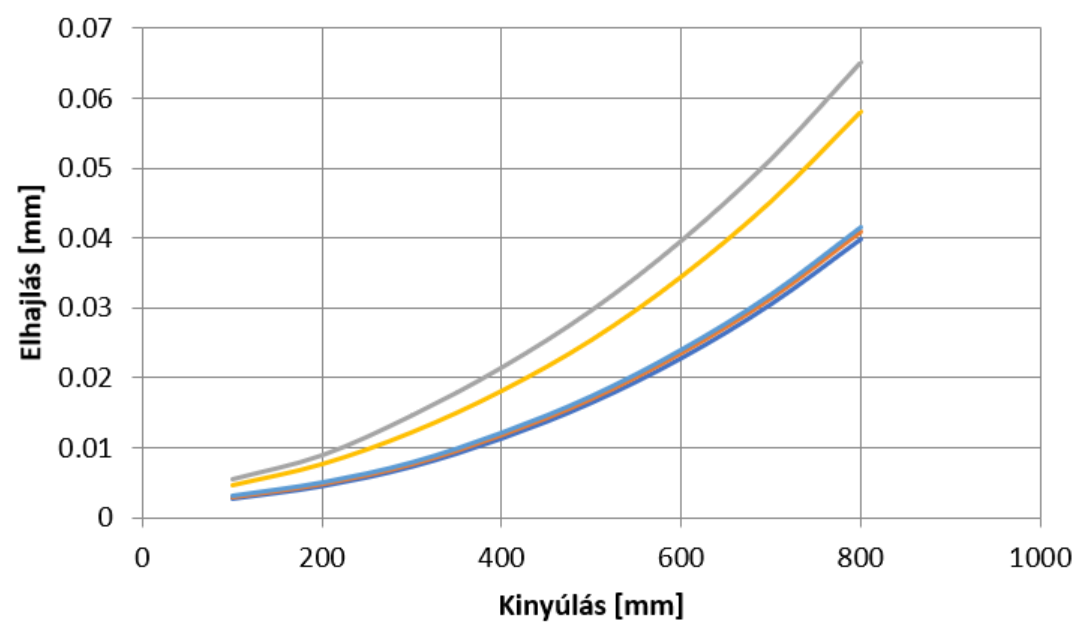

9. ábra. Az orsótöke kitüntetett pontjának elmozdulása a kinyúlás függvényében adott hajlitó terhelés mellett.

A diagram görbéi eltérő orsótőke keresztmetszetekhez tartozó megvezetés-változatokra vonatkoznak. 6- és 8-szögletü keresztmetszetű, csúszó- vagy gördülőelemes megvezetésủ orsótőkeváltozatokat elemeztünk úgy, hogy a megvezető elemek helyzete és darabszáma is változott. Az alábbi ábra az orsótőkét hordozó orsóházban elhelyezett vezető elemek lökethossz menti helyzetét, és az adott keresztmetszetben elhelyezkedő megvezető elemek számát mutatja (10. ábra).

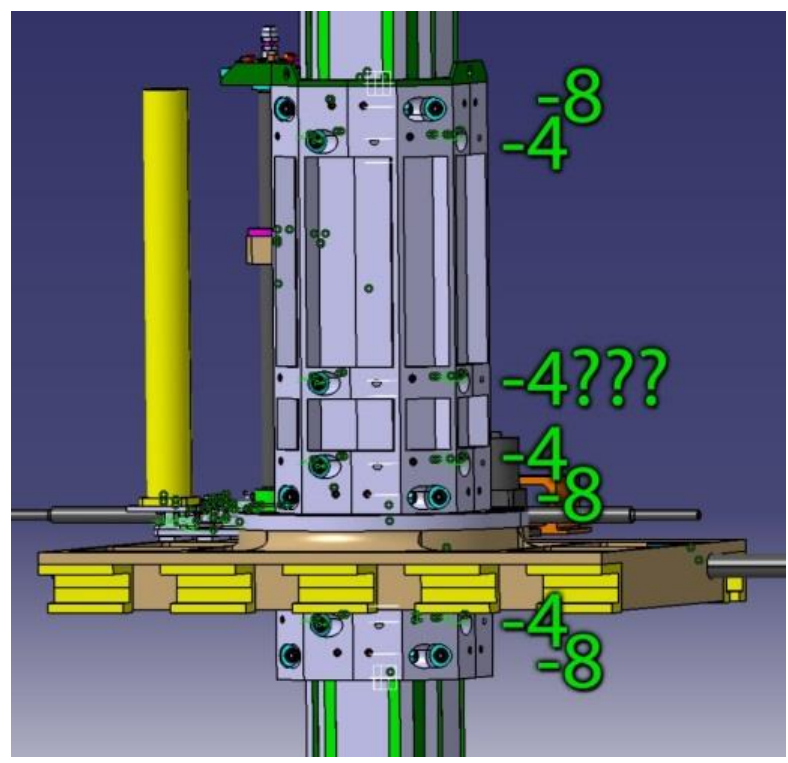

10. ábra. A nagyoló egység orsóháza a megvezetési keresztmetszetekkel. 
Hangsúlyozzuk továbbra is, hogy a terhelést - az egyszerüség kedvéért, és a gyors, előzetes megítélés végett - statikusnak tekintettük. A későbbiekben hasonló vizsgálatokat végeztünk időben változó terhelések mellett is.

Elvégeztük továbbá az X-ágy és az ágyon futó szánokat is tartalmazó összeállítási modell (11. ábra(bal)) szilárdságtani vizsgálatát. A számítás egyik részeredménye a szán elmozdulásmezőjére vonatkozott (11. ábra (jobb)).
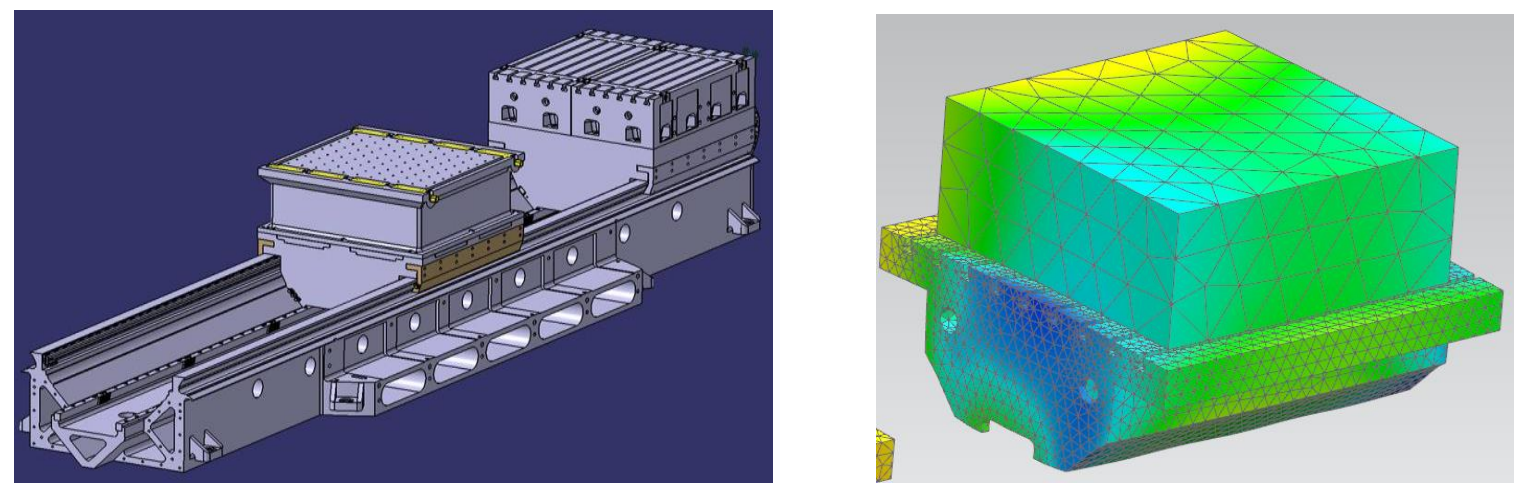

11. ábra. Az X-ágy és a rajta futó szánok geometriai modellje, illetve a számitás részeredménye.

Ekkor a térfogaton megoszló, valamint a nagyoló megmunkáló erő megfelelő komponenséből adódó terhelés hatására bekövetkező szilárdságtani állapotot (elmozdulás- és feszültségmező) ítéltük meg, és igyekeztünk a szánok, a gépágy, és a vezetékek statikai merevségét optimalizálni. Részben e számítások eredményeként adódó végleges geometria alapján készült el a tényleges ágyöntvény (12. ábra).

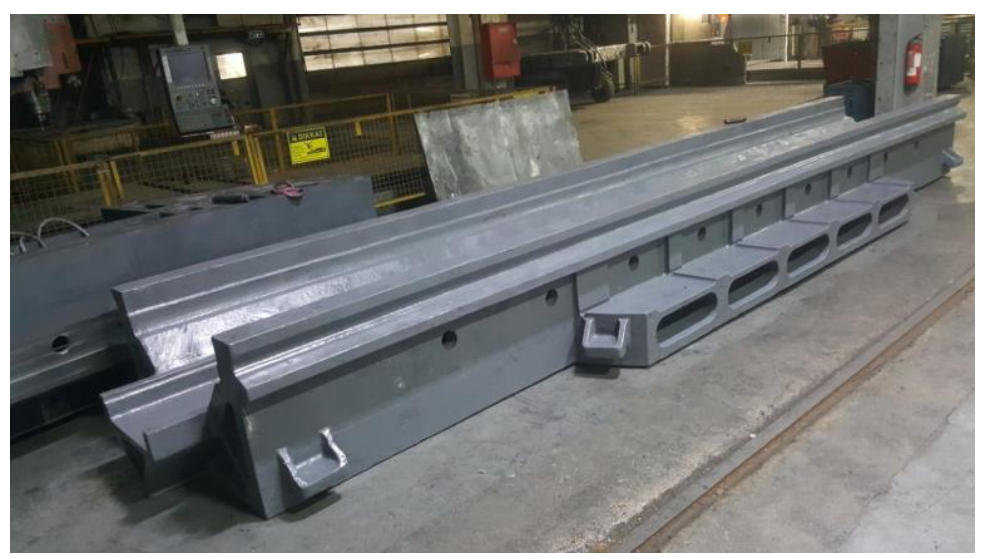

12. ábra. Az optimalizált geometriával elkészült öntvény.

\section{5. Összefoglalás}

Cikkünkben röviden áttekintettük azokat a lényegesebb müszaki jelenségköröket, amelyek leggyakrabban és legnagyobb súllyal fordulnak elö megmunkálóberendezések üzemeltetése során. Kitértünk arra is, hogy a vázolt jelenségkörök nagyrésze - legalábbis jelenleg - egzakt analitikus módon csak körülményesen vagy egyáltalán nem kezelhetö. Rámutattunk, hogy ilyenkor célszerü a 
mechanika és a hőtan numerikus eszközeit alkalmazni, melyek közül talán a végeselemes analízis a legismertebb és legelterjedtebb a gépészmérnöki gyakorlatban. Példák segítségével igazoltuk e numerikus eljárás sokrétüségét és hatékonyságát. A cikkben említett végeselemes eljárással kapcsolatban kijelenthetjük, hogy - mind a berendezés tervezési, mind annak üzemeltetési fázisában kényelmes elméleti eszköz számos eltérö jelenségkörből fakadó probléma feltárásra és vizsgálatára. Különösen alkalmas összehasonlító elemzésekre, és döntő szerepet játszott konstrukciós „zsákutcák” felismerésében. Ugyanakkor - az optimális számítási idő és pontosság elérése érdekében - figyelmet igényel a végeselemes háló minősége, különös tekintettel az érintkezési feladatokra.

\section{Köszönetnyilvánítás}

A cikkben ismertetett kutató munka az EFOP-3.6.1-16-2016-00011 jelü „Fiatalodó és Megújuló Egyetem - Innovatív Tudásváros - a Miskolci Egyetem intelligens szakosodást szolgáló intézményi fejlesztése" projekt részeként - a Széchenyi 2020 keretében - az Európai Unió támogatásával, az Európai Szociális Alap társfinanszírozásával valósul meg.

\section{Irodalom}

[1] Baráti, A.: Szerszámgép vizsgálatok, Műszaki Könyvkiadó, Budapest, 1988.

[2] Faragó, K.: Szíjhajtású szerszámgép főorsók nemlineáris rezgései, Kandidátusi értekezés, Miskolc, 1985.

[3] Kollányi, T.: Szíjágak transzverzális lengései, PhD-értekezés, Miskolc, 2003.

[4] Mekid, S.: Introduction to precision machine design and error assessment, CRC Press, 2009.

[5] Páczelt, I.: Végeselemmódszer a mérnöki gyakorlatban I. kötet, Miskolci Egyetemi Kiadó pp.36-37.

[6] Patkó, Gy.: Dinamikai eredmények és alkalmazások a géptervezésben, Habilitációs füzet, Miskolc, 1998.

[7] Patkó, Gy.: Közelítő módszer nemlineáris rezgések vizsgálatára, Kandidátusi értekezés, Miskolc, 1984. 